\title{
DAMPAK SERTIFIKASI DAN PENDIDIKAN TERAKHIR TERHADAP KINERJA GURU PAUD DI KABUPATEN PONOROGO
}

\author{
Popila Rikma Nusa \\ Institut Agama Islam Negeri Ponorogo \\ Email: popilanusa@gmail.com \\ Edi Irawan \\ Institut Agama Islam Negeri Ponorogo \\ Email: nawariide@iainponorogo.ac.id
}

\begin{abstract}
Certification allowance comes as a form of appreciation for professional teacher performance. However, the reality is that there are still many teachers who are not yet certified educators. This study aims to determine: 1) Is there a difference in the performance of PAUD teachers who are already certified and not certified; 2) Is there a difference in the performance of PAUD teachers with PAUD / Psychology and non PAUD I non Psychology education; 3) Is there an interaction between certification and recent education on the performance of PAUD teachers. This research uses a quantitative method with a comparative causal approach. with simple random sampling. Data analysis was performed using the two-way ANOVA test. The results of the study show that: 1) The performance of certified teachers is better than those not certified; 2) The performance of PAUD teachers with PAUD / Psychology and non PAUD / Psychology last education is equally good; 3) There is no interaction between certification and educational background on the performance of PAUD teachers.
\end{abstract}

Keywords: certification, educational background, PAUD teacher performance

\begin{abstract}
Abtrak: Tunjangan sertifikasi hadir sebagai salah satu bentuk apresiasi terhadap kinerja guru yang profesional. Namun, kenyataan yang ada masih banyak guru yang belum bersertifikat pendidik. Penelitian ini bertujuan untuk mengetahui: 1) Apakah terdapat perbedaan kinerja guru PAUD yang sudah tersertifikasi dan belum sertifikasi; 2) Apakah terdapat perbedaan kinerja guru PAUD dengan pendidikan terakhir PAUD/Psikologi dan non PAUD/ non Psikologi; 3) Apakah terdapat interaksi antara sertifikasi dan pendidikan terakhir terhadap kinerja guru PAUD. Penelitian ini menggunakan metode kuantitatif dengan jenis pendekatan kausal komparatif. ngan pengambilan sampel secara simple random sampling. Analisis data dilakukan dengan menggunakan uji ANOVA dua jalan. Hasil penelitian menunjukkan bahwa: 1) Kinerja guru yang telah tersertifikasi lebih baik dibandingkan yang belum sertifikasi; 2) Kinerja guru PAUD dengan pendidikan terakhir PAUD/Psikologi dan non PAUD/Psikologi sama baiknya; 3) Tidak terdapat interaksi antara sertifikasi dan latar belakang pendidikan terhadap kinerja guru PAUD.
\end{abstract}

Kata kunci: sertifikasi, latar belakang pendidikan, kinerja guru PAUD 


\section{PENDAHULUAN}

Sertifikasi adalah suatu proses pemberian sertifikat atau penghargaan pendidik untuk guru dan dosen. Sedangkan sertifikasi pendidik adalah bukti formal sebagai pengakuan yang diberikan kepada guru dan dosen sebagai tanda profesional. ${ }^{1}$ Sertifikasi guru merupakan amanat Undang- undang Republik Indonesia No 20 tahun 2003 tentang Sistem Pendidikan Nasional. Pada pasal 61 menyatakan bahwa sertifikasi yang diberikan dapat berbentuk ijazah dan sertifikat kompetensi, tetapi bukan sertifikat yang diperoleh melalui pertemuan ilmiah seperti seminar, diskusi panel, loka karya, dan simposium. ${ }^{2}$ Sertifikat kompetensi didapat dari penyelenggara pendidikan dan lembaga pelatihan setelah dinyatakan lulus dari uji kompetensi yang diselenggarakan oleh satuan pendidikan yang terakreditasi atau lembaga sertifikasi.

Sertifikasi guru merupakan upaya nyata pemerintah dalam meningkatkan kualitas guru sebagai tenaga pendidik dan pengajar dinilai dari kualitas diri dan kinerjanya. Dengan adanya upaya dari pemerintah ini, diharapkan dapat diketahui kelayakan pendidik menyandang predikat sebagai guru profesional. Dalam hal ini, program sertifikasi yang direalisasikan oleh pemerintah selain untuk meningkatkan kualitas kompetensi pendidik, juga untuk meningkatkan kesejahteraan hidup guru. ${ }^{3}$ Sertifikasi guru diberikan baik pada calon guru lulusan LPTK (Lembaga Pendidikan dan Tenaga Kependidikan) maupun berasal dari PT (Perguruan Tinggi) non kependidikan yang ingin memilih guru sebagai profesi. Lulusan dari perguruan tinggi non kependidikan, sebelum mengikuti uji sertifikasi diharuskan untuk mengikuti program pembentukan kemampuan mengajar di LPTK.

\footnotetext{
1 Undang-Undang No. 14 Tahun 2005 Tentang Guru dan Dosen, Pasal 1

${ }^{2}$ UmarSidiq, Etika \& Profesi Keguruan, (Tulungagung: STAI

Muhammadiyah, 2018), 75

${ }^{3}$ lbid, 77
} 
Latar belakang pendidikan dan tingkat jabatan sangat berpengaruh terhadap keberhasilan seorang guru dalam mengajar. Guru harus dapat menyesuaikan bahan- bahan pembelajaran dengan keadaan dan tempat serta latar belakang perkembangan anak. Latar belakang pendidikan guru yang mempersyaratkan bahwa pendidik harus memiliki kualifikasi minimum dan sertifikasi sesuai dengan kewenangan mengajar, sehat jasmani dan rohani, dan memiliki kemampuan untuk mewujudkan tujuan pendidikan nasional penjelasan tersebut tercantum pada Undang-Undang Republik Indonesia No. 20 Tahun 2003 tentang Sistem Pendidikan Nasional Pernyataan tersebut ditegaskan kembali dalam Pasal 28 Peraturan Pemerintah RI No. 19 Tahun 2005 tentang Standar Pendidikan Nasional, dan pada pasal 8 Undang-Undang RI No 14 Tahun 2005 yang menjelaskan bahwa guru harus memiliki kualifikasi akademik minimal pada jenjang pendidikan D4/S1 dan memiliki kompetensi sebagai agen pembelajaran, yang meliputi kompetensi pedagogik, sosial, kepribadian, dan profesional. Kompetensi guru sebagai agen pembelajaran secara formal dibuktikan dengan adanya sertifikat pendidik. ${ }^{4}$ Dengan adanya peraturan pemerintah tersebut, diharapkan kualitas tenaga pendidik semakin membaik dan tidak ada lagi guru yang memiliki latar belakang pendidikan setingkat SMA.

Pada PAUD/TK/RA adapun kualifikasi akademik guru harus memiliki jenjang pendidikan minimal diploma empat (D4) atau Sarjana (S1) dalam bidang PAUD atau psikologi yang diperoleh dari program studi yang terakreditasi. ${ }^{5}$ Seiring dengan adanya tuntutan mutu dari pendidikan, maka pemerintah membuat peraturan perundang-undangan yang mengatur tentang kualifikasi, kompetensi, dan sertifikasi guru. Dalam Pasal 29 ayat 1 PP Nomor 19 Tahun 2005 tentang Standar Nasional

\footnotetext{
${ }^{4}$ Maryono, Dasar-Dasar \& Teknik Menjadi Supervisor Pendidikan, (Jogjakarta: Ar-Ruzz Media, 2011), 89 .

5 Abd. Kadim Masaong, Supervisi Pembelajaran dan Pengembangan Kapasitas Guru, (Bandung: Alfabeta, 2013), 104
} 
Pendidikan, pendidik pada anak usia dini haruslah memiliki: (a) kualifikasi akademik pendidikan minimal diploma empat (D-4) atau sarjana (S1); (b) latar belakang pendidikan tinggi di bidang pendidikan anak usia dini, kependidikan yang lain, atau psikologi; dan (c) sertifikasi profesi untuk guru PAUD ${ }^{6}$.

Kualifikasi dan kompetensi guru PAUD didasarkan pada Permendiknas RI Nomor 16 Tahun 2007 tentang Standar Kualifikasi Akademik dan Kompetensi Guru beserta lampirannya. Bagi pendidik PAUD pada jalur pendidikan formal (TK, RA, yang sederajat) dan pendidik PAUD pada jalur pendidikan non formal (TPA, KB, dan yang sederajat) yang belum memenuhi kualifikasi akademik dan kompetensi pendidik disebut guru pendamping dan pengasuh. ${ }^{7}$

Kinerja guru dapat disebut sebagai tingkat keberhasilan guru dalam melaksanakan tugas profesinya sesuai dengan tanggung jawab dan wewenang yang dimiliki berdasarkan standar kinerja yang telah ditetapkan selama periode yang telah ditetapkan dalam rangka mencapai tujuan pendidikan. Kinerja guru dapat dilihat dan diukur dengan spesifikasi kompetensi yang harus dimiliki oleh setiap guru.

Raudatul Athfal (RA) sendiri merupakan salah satu bentuk pendidikan anak usia dini yang ada pada jalur formal. Pendidikan RA berguna untuk membantu pertumbuhan dan perkembangan anak secara jasmani maupun rohani sebelum memasuki pendidikan sekolah dasar. tugas utama pendidikan RA adalah menyiapkan mental, sikap, perilaku, pengetahuan, keterampilan, dan intelektual anak sehingga anak dapat dengan mudah beradaptasi dengan kegiatan pembelajaran yang

6 Kunandar, Guru Profesional Implementasi Kurikulum Tingkat Satuan Pendidikan (KTSP) dan Sukses dalam Sertifikasi Guru, (Jakarta: Rajawali Pers, 2009), 73.

${ }^{7}$ Mukhtar Latif dkk, Orientasi Baru Pendidikan Anak Usia Dini, (Jakarta: Kencana, 2016), 247 
sesungguhnya pada sekolah dasar. ${ }^{8}$ Penjelasan tersebut sejalan dengan dokumen Kurikulum Berbasis Kompetensi yang mnegaskan bahwa pendidikan anak usia dini (PAUD) adalah upaya pemberian rangsangan, membimbing, mengasuh, dan memberi kegiatan yang akan menghasilkan kemampuan dan keterampilan pada anak. ${ }^{9}$ Hasil observasi yang dilakukan peneliti di beberapa PAUD yang terletak di Kabupaten Ponorogo, dapat diketahui bahwa ada beberapa guru yang masih belum memperhatikan kinerjanya. Hal tersebut ditunjukkan dengan adanya guru yang masih belum memperhatikan tentang pentingnya perencanaan, pelaksanaan, penilaian, dan pengevaluasian pembelajaran. Adanya guru yang masih mengabaikan penilaian pembelajaran, pertumbuhan dan perkembangan anak didiknya. Dengan timbulnya permasalahan tersebut berdampak kepada adanya sebagian anak yang kurang tertarik mengikuti proses pembelajaran di dalam kelas.

Masalah lain yang timbul adalah tentang jenjang pendidikan dan latar belakang pendidikan terakhir yang dimiliki guru yaitu SMA ataupun S1 yang tidak pada bidangnya, sebagaimana yang disebutkan di atas bahwa pada pendidikan anak usia dini pendidik memiliki kualifikasi akademik minimum D4/S1 di bidang pendidikan anak usia dini, kependidikan lain, atau psikologi.

Setelah melihat uraian di atas, tampak bahwa kinerja guru di sekolah sangat dipengaruhi oleh sertifikasi, lingkungan sekolah, sarana dan prasarana, kepemimpinan, kualifikasi akademik pendidik, dan latar belakang pendidikan guru. Lemahnya kinerja guru dalam manajemen pendidikan tersebut akan berdampak pada mutu pendidikan pada sekolah menjadi kurang optimal, dan juga tak luput mempengaruhi kualitas SDM

${ }^{8}$ Fika Septiana Sari, Meningkatkan Kemampuan Bahasa Reseptif Anak Melalui Metode Bercerita Kelompok B RA Raudlotul Ulum Pasuruan, Vol. 6 Nomor 1 Februari 2020, 2425

${ }^{9}$ Berda Asmara, Meningkatkan Kemampuan Motorik Halus Melalui Kegiatan Menggunting Pada Anak Usia Dini di Kelompok A TK Khadijah Surabaya, Vol. 6 Nomor 1 Januari 2020, 12. 
yang kurang mampu bersaing pada jenjang pendidikan selanjutnya. Hal ini dapat menunjukkan bahwa peran guru sangat penting dalam proses belajar dan hasil belajar anak merupakan cerminan dari kualitas kinerja guru. Rendahnya profesionalitas guru, kurangnya fasilitas pendidikan, dan ketidaksesuaian latar belakang pendidikan guru menjadi masalah yang muncul saat ini.

Masalah-masalah di atas saling berkaitan dan menciptakan kondisi pendidikan yang kurang kondusif bagi guru untuk menunjukkan sebagai guru yang profesional sehingga mampu menciptakan SDM yang bermutu. Bertitik tolak dari permasalahan di atas, maka tujuan penelitian adalah untuk mengetahui: 1) Apakah terdapat perbedaan kinerja guru PAUD yang sudah tersertifikasi dan belum sertifikasi; 2) Apakah terdapat perbedaan kinerja guru PAUD dengan pendidikan terakhir PAUD/Psikologi dan non PAUD/ non Psikologi; 3) Apakah terdapat interaksi antara sertifikasi dan pendidikan terakhir terhadap kinerja guru PAUD.

\section{METODE PENELITIAN}

Penelitian ini menggunakan pendekatan kuantitatif dengan jenis kausal komparatif. Terdapat dua variabel bebas dan satu variabel terikat.Variabel bebas pertama (X1) adalah status sertifikasi guru, yang terdiri dari dua ketegori, yaitu sudah sertifikasi dan belum sertifikasi. Variabel bebas kedua (X2) adalah latar belakang pendidikan, yang juga terdiri dari dua kategori, yaitu berpendidikan terakhir PAUD/Psikologi dan berpendidikan terakhir non PAUD/non Psikologi. Sedangkan untuk variabel terikatnya $(Y)$ adalah kinerja guru PAUD yang diukur menggunakan angket.

Populasi pada penelitian ini ini adalah guru PAUD di Kabupaten Ponorogo. Sampel yang diambil menggunakan teknik simple random sampling. Pada penelitian dengan jumlah populasi berkisar 100 ke atas, 
maka dapat diambil sampel sebesar 10\% - 15\% atau 20\% - 25\%. ${ }^{1010}$ Oleh karena itu pada penelitian ini, untuk mengambil sampel sebanyak 101 dari total populasi guru PAUD sejumlah 1.014.

Pengumpulan data dilakukan dengan menggunakan angket tertutup tentang status sertifikasi, latar belakang pendidikan dan sekaligus kinerja guru. Teknik keabsahan data dilakukan dengan menggunakan validitas dan reliabilitas instrumen. Instrumen yang digunakan telah memenuhi validitas isi dan validitas butir. Hasil uji menggunakan Cronbach Alpha juga menghasilkan koefisien yang tinggi $(0,999)$ sehingga bisa disimpulkan bahwa instrumen reliabel.

Teknik analisis data yang digunakan adalah ANOVA dua jalan ( Two Way ANOVA). Secara teknis, analisis data dilakukan dengan bantuan software SPSS for Windows $21 .^{11}$

\section{HASIL DAN PEMBAHASAN}

Berdasarkan hasil angket, diperoleh data tentang kondisi guru PAUD di Kabupaten Ponorogo sebagaimana tercantum pada tabel 1 di bawah, Tabel 1. Jumlah Guru PAUD Berdasarkan Status Sertifikasi dan Latar Belakang Pendidikannya

\begin{tabular}{|c|c|c|c|c|}
\hline & \multicolumn{2}{|c|}{ Status Sertifikasi } & \multirow[t]{2}{*}{ Jumlah } \\
\hline & & Sudah & Belum & \\
\hline \multirow{3}{*}{ 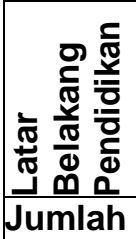 } & $\begin{array}{l}\text { PG - PAUD/ } \\
\text { Psikologi }\end{array}$ & 20 & 31 & 51 \\
\hline & $\begin{array}{l}\text { Non PG - PAUD/ } \\
\text { Psikologi }\end{array}$ & 13 & 18 & 31 \\
\hline & & 33 & 49 & 82 \\
\hline
\end{tabular}

Berdasarkan tabel di atas dapat dilihat bahwa responden dengan status sudah sertifikasi dan berlatar belakang pendidikan S1 PAUD/Psikologi sebanyak 20 responden, untuk responden dengan status sudah sertifikasi

10 Suharsimi Arikunto, Prosedur Penelitian Pendekatan Praktik, (Jakarta: Bina Aksara, 1987), 120.

11 Syofian Siregar, Metode Penelitian Kuantitatif dilengkapi dengan Perbandingan Perhitungan Manual \& SPSS, 22 
dan berlatar belakang S1 non PAUD/non Psikologi sebanyak 13 responden, sedangkan responden dengan status belum sertifikasi dan berlatar belakang S1 PAUD/Psikologi sebanyak 31 responden, dan untuk responden dengan status belum sertifikasi dan berlatar belakang $\mathrm{S} 1$ non PAUD/non Psikologi sebanyak 18 responden. Dari penjelasan berikut dapat disimpulkan bahwa mayoritas pendidik belum berstatus sertifikasi dengan berlatar belakang S1 PAUD/Psikologi. Selanjutnya, berdasarkan hasil angket kinerja guru diperoleh data rerata kinerja guru PAUD pada masing-masing kelompok sebagaimana tercantum pada tabel 2 di bawah ini.

Tabel 2. Rerata Kinerja Guru PAUD Berdasarkan Status Sertifikasi dan Latar Belakang Pendidikannya

\begin{tabular}{|c|c|c|c|}
\hline & \multicolumn{2}{|c|}{ Status Sertifikasi } \\
\hline & & Sudah & Belum \\
\hline 유ำ & $\begin{array}{l}\text { PG - PAUD/ } \\
\text { Psikologi }\end{array}$ & 20 & 31 \\
\hline 离 & $\begin{array}{l}\text { Non PG - PAUD/ } \\
\text { Psikologi }\end{array}$ & 13 & 18 \\
\hline
\end{tabular}

Sebelum dilakukan uji anova dua jalan, berikut adalah hasil uji asumsi anova yang dilakukan dengan menggunakan software SPSS.

Tabel 3. Hasil Uji Normalitas

\begin{tabular}{|l|l|l|}
\hline Kelompok & Sig. & Kesimpulan \\
\hline Guru Bersertifikat & 0,200 & Normal \\
\hline $\begin{array}{l}\text { Guru Belum } \\
\text { Bersertifikat }\end{array}$ & 0,056 & Normal \\
\hline $\begin{array}{l}\text { Guru Lulusan PG } \\
\text { PAUD/Psikologi }\end{array}$ & 0,156 & Normal \\
\hline $\begin{array}{l}\text { Guru Lulusan } \\
\text { Non-PG PAUD/Psikologi }\end{array}$ & 0,200 & Normal \\
\hline
\end{tabular}

Hasil di atas menunjukkan bahwa nilai signifikansi data guru yang sudah bersertifikat sebesar 0,200, guru yang belum bersertifikat sebesar 0,056, 
nilai signifikansi data guru lulusan S1 PAUD/Psikologi sebesar 0,156 dan data guru gengan lulusan S1 non PAUD/ non Psikologi sebesar 0,200. Dari keseluruhan uji normalitas di atas $>0,05$. Maka dapat disimpulkan bahwa data tersebut berdistribusi normal.

Tabel 4. Hasil Uji Homogenitas

\begin{tabular}{|l|l|l|}
\hline Komparasi & Sig. & Kesimpulan \\
\hline Status Sertifikasi & 0,354 & Homogen \\
\hline $\begin{array}{l}\text { Latar Belakang } \\
\text { Pendidikan }\end{array}$ & 0,156 & Homogen \\
\hline
\end{tabular}

Dari tabel di atas menunjukkan bahwa nilai signifikansi sertifikasi sebesar 0,354, dan nilai signifikansi latar belakang pendidikan sebesar 0,156. Dari keseluruhan uji homogenitas di atas $>0,6$. Sehingga dapat disimpulkan bahwa data homogen atau sama.

Selanjutnya, berikut adalah hasil uji anova dua jalur menggunakan software SPSS.

Tabel 5. Hasil Uji Two Way ANOVA

\begin{tabular}{|l|r|r|r|r|r|}
\hline \multicolumn{7}{|c|}{ Tests of Between-Subjects Effects } \\
\hline Dependent Variable: kinerja_guru \\
\hline Source & $\begin{array}{l}\text { Type III Sum of } \\
\text { Squares }\end{array}$ & df & $\begin{array}{c}\text { Mean } \\
\text { Square }\end{array}$ & F & Sig. \\
\hline $\begin{array}{l}\text { Corrected } \\
\text { Model }\end{array}$ & $42.786^{\mathrm{a}}$ & 3 & 14.262 & 1.578 & .201 \\
\hline Intercept & 420203.848 & 1 & 420203.848 & 46505.47 & .000 \\
\hline Sertifikasi & 40.952 & 1 & 40.952 & 4.532 & .036 \\
\hline LBP & 1.374 & 1 & 1.374 & .152 & .698 \\
\hline $\begin{array}{l}\text { sertifikasi } \\
\text { * LBP }\end{array}$ & .785 & 1 & .785 & .087 & .769 \\
\hline Error & 704.775 & 78 & 9.036 & & \\
\hline Total & 461098.000 & 82 & & & \\
\hline $\begin{array}{l}\text { Corrected } \\
\text { Total }\end{array}$ & 747.561 & 81 & & & \\
\hline a. R Squared $=.057$ (Adjusted R Squared $=.021$ ) & & \\
\hline
\end{tabular}


Berdasarkan table tersebut didapat data bahwa:

1. Berdasarkan tabel di atas, diketahui Nilai signifikan sivariabel sertifikasi sebesar 0,036 hal ini kurang dari0,05 (taraf signifikansi), akibatnya $\mathrm{H}_{0}$ ditolak sehingga bisa disimpulkan bahwa terdapat perbedaan kinerja guru yang sudah tersertifikasi dan yang belum tersertifikasi. Berdasarkan rerata nilai kinerja guru sebagaimana tercantum pada tabel 2 di atas, terlihat bahwa rerata kinerja guru yang sudah tersertifikasi sebesar 75,813 sedangkan rerata kinerja guru yang sudah tersertifikasi sebesar 74.378. Hal ini berarti kinerja guru RA dengan status sudah tersertifikasi lebih baik daripada kinerja guru RA dengan status belum tersertifikasi.

2. Nilai signifikansi variabel latar belakang pendidikan sebesar 0,698 hal ini lebih dari0,05 (taraf signifikansi), akibatnya $\mathrm{H}_{0}$ diterima sehingga bisa disimpulkan bahwa tidak terdapat perbedaan kinerja guru PAUD berdasarkan latar belakang pendidikannya. Diketahui nilai signifikansi variabel $0,769>0,05$ sehingga $\mathrm{H}_{0}$ diterima. Hal ini berarti tidak terdapat interaksi antara sertifikasi dan latar belakang pendidikan terhadap kinerja guru PAUD.

\section{PEMBAHASAN}

Hasil ke 1, Terdapat Pengaruh Antara Sertifikasi terhadap Kinerja Guru PAUD. Hasil penelitian ini sejalan dengan teori yang dikemukakan oleh Mulyasa bahwa proses sertifikasi guru menuju profesionalisme pelaksanaan tugas dan fungsinya harus dibarengi dengan kenaikan kesejahteraan guru sistem rekrutmen guru, pembinaan, peningkatan karir guru. Kesejahteraan guru dapat diukur dari gaji dan insentif yang diperoleh. Gaji guru di Indonesia masih relatif rendah dibandingkan dengan negara- negara lain. Rendahnya kesejahteraan guru dapat 
mempengaruhi kinerja guru, semangat pengabdiannya, dan juga upaya mengembangkan profesionalismenya. ${ }^{12}$

Hasil ke 2, Tidak Terdapat Pengaruh Antara Latar Belakang Pendidikan terhadap Kinerja Guru PAUD. Hasil penelitian ini sejalan dengan penelitian terdahulu yang dilakukan oleh Indrawati Noor Kamila dengan judul penelitian perbedaan kinerja mengajar guru pendidikan anak usia dini ditinjau dari latar belakang pendidikan (Penelitian Ex Post Facto Pada Guru Taman Kanak-kanak Di Kabupaten Ciamis Provinsi Jawa Barat Tahun Pelajaran 2015/2016) dengan hasil penelitian menunjukkan bahwa tidak terdapat perbedaan yang signifikan kinerja mengajar guru yang ditinjau dari latar belakang pendidikan.

Hasil ke 3, Tidak Terdapat Interaksi Antara Sertifikasi dan Latar Belakang Pendidikan terhadap Kinerja Guru PAUD. Hal ini tidak sejalan dengan hipotesis peneliti, bahwa ternyata kinerja guru RA dengan latar belakang PG- PAUD/Psikologi dan kinerja guru RA dengan latar belakang Non PAUD/Non Psikologi sama baiknya, dan itu konsisten baik untuk yang sudah berstatus sertifikasi maupun untuk yang berstatus belum sertifikasi. Demikian juga bahwa kinerja guru yang sudah bersertifikasi lebih baik daripada kinerja guru yang belum bersertifikasi, baik secara umum maupun secara khusus pada guru RA dengan latar belakang pendidikan PG-PAUD/Psikologi maupun yang Non PAUD/Non Psikologi.

\section{KESIMPULAN}

Berdasarkan hasil analisis dan pembahasan di atas, maka dapat disimpulkan bahwa:

1. Terdapat pengaruh yang signifikan antara status sertifikasi terhadap kinerja guru PAUD di Kabupaten Ponorogo. Hal itu dapat dilihat bahwa nilai signifikansi variabel sertifikasi $0,036<0,05$ yang artinya

\footnotetext{
${ }^{12}$ E. Mulyasa, Standar Kompetensi dan Sertifikasi Guru, 35.
} 
$\mathrm{H}_{0}$ ditolak. Nilai rata-rata kinerja guru PAUD dengan status sudah tersertifikasi sebesar 75,813 dan nilai rata-rata kinerja guru PAUD dengan status belum tersertifikasi 74,378 . Hal ini berarti kinerja guru PAUD di Kabupaten Ponorogo pada Tahun Ajaran 2019/2020 dengan status sudah tersertifikasi lebih baik daripada kinerja guru PAUD dengan status belum tersertifikasi. Sehingga dapat disimpulkan bahwa status sertifikasi dapat meningkatkan kinerja guru PAUD di Kabupaten Ponorogo pada tahun Ajaran 2019/2020. Tidak terdapat pengaruh yang signifikan antara latar belakang pendidikan terhadap kinerja guru PAUD di Kabupaten Ponorogo pada Tahun Ajaran 2019/2020. Hal itu dapat dilihat bahwa nilai signifikansi variabel latar belakang pendidikan 0,698 > 0,05 yang artinya $\mathrm{H}_{0}$ diterima. Hasil tersebut menjelaskan bahwa kinerja guru PAUD di Kabupaten Ponorogo dengan latar belakang pendidikan PG-PAUD/Psikologi sama baiknya kinerja guru PAUD dengan latar belakang pendidikan Non PAUD/Non Psikologi.

2. Tidak terdapat interaksi antara sertifikasi dan latar belakang pendidikan terhadap kinerja guru PAUD di Kabupaten Ponorogo pada Tahun Ajaran 2019/2020. Hal itu dapat dilihat setelah dilakukannya uji Two Way ANOVA oleh peneliti yang menghasilkan nilai signifikansi $0,769>0,05$ sehingga $\mathrm{H}_{0}$ diterima. Maka dapat disimpulkan bahwa tidak ada interaksi antara sertifikasi dan latar belakang pendidikan terhadap kinerja guru PAUD di Kabupaten Ponorogo pada Tahun Ajaran 2019/2020. Hal ini menjelaskan bahwa ternyata kinerja guru PAUD dengan latar belakang PGPAUD/Psikologi dan kinerja guru RA dengan latar belakang Non PAUD/Non Psikologi sama baiknya, dan itu konsisten baik untuk yang sudah berstatus sertifikasi maupun untuk yang berstatus belum sertifikasi. Demikian juga bahwa kinerja guru yang sudah tersertifikasi lebih baik daripada kinerja guru yang belum 
tersertifikasi, baik secara umum maupun secara khusus pada guru PAUD dengan latar belakang PG- PAUD/Psikologi maupun yang Non PAUD/Non Psikologi.

\section{DAFTAR PUSTAKA}

Arikunto, Suharsimi. Prosedur Penelitian Pendekatan Praktik. Jakarta: Bina Aksara, 1987. ISSN: $0854-7108$

Asmara, Berda. Meningkatkan Kemampuan Motorik Halus Melalui Kegiatan Menggunting Pada Anak Usia Dini di Kelompok A TK Khadijah Surabaya. Vol. 6, Nomor 1, Januari 2020. E-ISSN: 2599-042X.

Kunandar.Guru Profesional Implementasi Kurikulum Tingkat Satuan Pendidikan (KTSP) dan Sukses dalam Sertifikasi Guru. Jakarta: Rajawali Pers, 2009.

Latif, Mukhtar dkk. Orientasi Baru Pendidikan Anak Usia Dini: Teori dan Aplikasi. Jakarta: Kencana, 2016.

Maryono.Dasar-Dasar \& Teknik Menjadi Supervisor Pendidikan.. Jogjakarta: Ar-Ruzz Media, 2011.

Masaong, Abd. Kadim. Supervisi Pembelajaran dan Pengembangan Kapasitas Guru. Bandung: Alfabeta, 2013.

Septiana Sari, Fika. Meningkatkan Kemampuan Bahasa Reseptif Anak Melalui Metode Bercerita Kelompok B RA Raudlotul Ulum Pasuruan. Vol. 6, Nomor 1, Februari 2020. E- ISSN: 2599-042

Sidiq, Umar.Etika \& Profesi Keguruan. Tulungagung: STAI Muhammadiyah, 2018. 
WISDOM: JURNAL PENDIDIKAN ISLAM ANAK USIA DINI

Volume 01 No. 01, Juni 2020

Siregar, Syofian. Metode Penelitian Kuantitatif dilengkapi dengan Perbandingan Perhitungan Manual \& SPSS. Jakarta: Kencana, 2013.

Soetarlinah Sukadji, Awas: Studi Kausal- Komparatif, Buletin Psikologi, Tahun V, Nomor 2, Desember 1997,।

Trianto.Pengantar Penelitian Pendidikan bagi Pengembangan Profesi Pendidikan \& Tenaga Kependidikan. Jakarta: Kencana Prenada Media Grup, 2011.

Undang-Undang No. 14 Tahun 2005 Tentang Guru dan dosen. 